\title{
Tetrastigma diepenhorstii (Miq.) Latiff (Vitaceae), a New Host of Rafflesia tuan-mudae Becc. (Rafflesiaceae) in Borneo
}

\author{
Wan Nuur Fatiha Wan Zakaria, ${ }^{1}$ Aida Shafreena Ahmad Puad, ${ }^{1}$ Connie Geri, ${ }^{2}$ \\ Ramlah Zainudin, ${ }^{3}$ and Abdul Latiff ${ }^{4}$ \\ ${ }^{1}$ Department of Plant Science and Environmental Ecology, Faculty of Resource Science and Technology, Universiti Malaysia Sarawak, \\ 94300 Kota Samarahan, Sarawak, Malaysia \\ ${ }^{2}$ Sarawak Forestry Corporation, 93050 Kuching, Sarawak, Malaysia \\ ${ }^{3}$ Department of Zoology, Faculty of Resource Science and Technology, Universiti Malaysia Sarawak, \\ 94300 Kota Samarahan, Sarawak, Malaysia \\ ${ }^{4}$ Department of Botany, Faculty of Science and Technology, Universiti Kebangsaan Malaysia, 43600 Bangi, Selangor, Malaysia
}

Correspondence should be addressed to Aida Shafreena Ahmad Puad; apashafreena@unimas.my

Received 30 April 2016; Accepted 20 September 2016

Academic Editor: Curtis C. Daehler

Copyright (C) 2016 Wan Nuur Fatiha Wan Zakaria et al. This is an open access article distributed under the Creative Commons Attribution License, which permits unrestricted use, distribution, and reproduction in any medium, provided the original work is properly cited.

\begin{abstract}
Rafflesia tuan-mudae Becc. (Rafflesiaceae) is endemic to Borneo and was recorded from Sarawak and probably Kalimantan. Previous records showed that Tetrastigma rafflesiae (Miq.) Planch. (Vitaceae) is the only host plant for R. tuan-mudae. In this study the host plants were collected each time $R$. tuan-mudae was observed or collected. Out of 20 Tetrastigma specimens collected infected by $R$. tuan-mudae, 14 were identified as T. diepenhorstii (Miq.) Latiff while 6 belonged to T. rafflesiae. Therefore, a new host for R. tuan-mudae is recorded and descriptions for each host are presented.
\end{abstract}

\section{Introduction}

Rafflesiaceae is a plant family that consists of eight genera Apodanthes Poit., Bdallophytum Eichler, Cytinus L., Mitrastema Makino, Pilostyles Guillemin, Rafflesia R. Br. ex Gray, Rhizanthes Dumort., and Sapria Griffith with about 55 species recorded. All members in this family are obligate parasites and rootless and have no chlorophyll and therefore are dependent on the host plants for water, nutrients, and survival [1]. Currently, the genus Rafflesia consists of about 34 species and is distributed in the Southeast Asian region [1-6].

Some species of the genus Tetrastigma (Miq) Planch. (Vitaceae), a woody vine, are the host plants for Rafflesia species [1]. Tetrastigma is distributed mainly in the Asian tropics, ranging from India to China, across Southeast Asia, eastward towards Fiji and extending towards subtropical Australia [7]. The species climb using tendrils, which develop opposite the leaf [8]. There are a few that have been reported as the host plant for many Rafflesia species, namely, T. curtisii (Ridl.) Suess., T. diepenhorstii (Miq.) Latiff, T. glabratum Planch., T. papillosum Planch., and T. rafflesiae Planch. [1, 911]. However, the latter is the host plant for most Rafflesia species and also for Rhizanthes zippelii (Blume) Spach [1,9]. Establishing the identity of the host plants is difficult mainly because they were usually not collected together with the Rafflesia [1]. Observations of 771 herbarium specimens from various herbaria such as BO, KEP, SAN, SAR, SING, SNP, and UKMB showed that there were only two records of Tetrastigma as the host. An example is shown by R. keithii (Coll. number SNP4088) where T. diepenhorstii is mentioned. Moreover, the hosts that were collected were sterile with no fruits or flowers, thus making reliable identification virtually impossible [1]. An ongoing study by Wan Nuur Fatiha Wan Zakaria is in progress to identify the sterile Tetrastigma species using molecular tools.

Rafflesia tuan-mudae Becc., commonly known as Pakma by the locals [12], is one of the Rafflesia species endemic to 
Borneo [1]. The type specimen was collected from Mount Pueh, Sematan, Sarawak, and was described by Beccari in 1868 [1]. It is reported that T. rafflesiae is the host for $R$. tuan-mudae [1]. The Rafflesia is distributed in other parts of Sarawak such as Gunung Gading National Park, Mount Rara, and Mount Penrissen. Possibly it can be found in Cagar Alam Gunung Raya Pasi near Singkawang, around Pontianak, and the upper Kayan River in Kalimantan [1]. It inhabits lowland and hill dipterocarp forests and can be found at up to about $900 \mathrm{~m}$ above sea level. Based on Wildlife Protection Ordinance 1998, all Rafflesia species in Sarawak are totally protected. In this study, a new host plant for $R$. tuan-mudae is recorded based on sampling from several populations in western Sarawak.

\section{Materials and Methods}

The study was carried out at Gunung Gading National Park (Lundu), Mount Pueh (Sematan), Tapak Rafflesia Kampung Temurang (Padawan), and Batang Ai National Park (Sri Aman). The host plants were collected together with the blooming flowers and young buds of $R$. tuan-mudae each time a collection or observation was made. The morphology of each Tetrastigma species was observed and measured in the field. This included growth habit, stem and stem lenticels, vegetative characteristics, and reproductive characteristics [8]. Collections were prepared as complete herbarium specimens and deposited at the Sarawak Herbarium (SAR), the Forest Research Centre, and the herbarium of Universiti Malaysia Sarawak.

\section{Results and Discussion}

A total of 20 Tetrastigma samples were collected. Of these, 14 were identified as $T$. diepenhorstii while six belonged to T. rafflesiae. Table 1 shows a list of species names, collection numbers, collection dates, localities, and collectors of the Tetrastigma species collected from four different populations.

It was reported that $T$. rafflesiae would be the only host for R. tuan-mudae [1]. However, this study showed that $T$. diepenhorstii is also a host making it the second host plant recorded for $R$. tuan-mudae. Descriptions of both Tetrastigma species observed and collected in this study are presented.

Tetrastigma rafflesiae (Miq.) Planch. (Figure 1). In DC., Monog. Phan. 5,2 (1887) 443; Suesseng. in Engler \& Prantl, Natur. Pflanzenfam. ed. 2, 20d (1953) 325. Basionym. Vitis rafflesiae Miq., Ann. Mus. Bot. Lugd. Bat. 1 (1863-64) 76. Lectotype: Sumatra, s. loc., Korthals s.n. xi/63 (L); T. tuberculatum (Blume) Latiff, Folia Malays. 2 (2001) 186; Cissus tuberculata Blume, Bijdr. 1 (1825) 189 - Type: Java, s.l. Blume s.n. (L) nom. superf.; T. lanceolarium (Roxb.) Planch. in DC. Monog. Phan. 5,2 (1887) 423; Suessenguth in Engler \& Prantl, Natur. Pflanzenfam. ed. 2, 20d (1953) 322; Backer \& Bakhuizen v.d. Brink, Fl. Java 2 (1965) 89; Latiff, Gard. Bull. Sing. 36,2 (1983) 222; Keng, Conc. Fl. Sing. (1990) 119. Cissus lanceolaria Roxb., Fl. Ind. 1 (1820) 430; Vitis lanceolarium (Roxb.) Wall. in Wight \& Arn., Prod. Fl. Ind. Orient. 1 (1834) 128; Miq., Fl. Ind. Bat. Suppl. 1 (1860-61) 603 et Ann. Mus. Bot.
Lugd. Bat. 1 (1863-64) 75; King, J. As. Soc. Beng. 65,2 (1896) 395; Backer, Schoolfl. Java (1911) 254; Ridley, Fl. Mal. Penin. 1 (1922) 475, nom. illeg. (include type of Cissus leucostaphylla). Type: Plants of Bengal, Vallia-tsjori-Valli, Rheede p. 430; T. mutabile (Blume) Planch. in DC., Monog. Phan. 5,2 (1887) 440; Suesseng. in Engler \& Prantl, Natur. Pflanzenfam. ed. 2, 20d (1953) 323; Backer \& Bakhuizen van den Brink, Fl. Java 2 (1967); Cissus mutabilis Blume, Bijdr. 1 (1825) 190; Miq., Fl. Ned. Indie 1,2 (1959) 605; Vitis mutabilis (Blume) Miq., Ann. Mus. Bot. Lugd. Bat. 1 (1863) 75. Holotype: Java, s. loc., Blume s.n. (L); T. encephalospermum Ridl., Bull. Misc. Inform. Kew (1926) 62. Type. Sumatra, Mentawai, Sipora Is., Boden Kloss SF 14643 (K, SING); Suesseng. in Engler \& Prantl, Natur. Pflanzenfam. ed. 2, 20d (1953) 322; T. kunstleri (King) Craib, Fl. Siam Enum. 1 (1926) 313; Suessenguth in Engler \& Prantl, Natur. Pflanzenfam. ed. 2, 20d (1953) 325. Vitis kunstleri King, J. As. Soc. Beng. 65,2 (1896) 396; Ridley, Fl. Mal. Penin. 1 (1922) 475. Holotype: Peninsular Malaysia, Perak, Larut, King's Collector 8027 (K, SING).

\section{Vernacular Name. Akar engkarana (Iban name).}

Climbing shrubs, climb up to $15 \mathrm{~m}$ high, large. Young stems terete, $2.6-4.1 \mathrm{~cm}$ in diameter, old stems terete, ca. $10 \mathrm{~cm}$ in diameter, or strap-like, $2.6-4.1 \mathrm{~cm}$ wide, ca. $2 \mathrm{~cm}$ thick, pustulate, young stems pustulate, terete. Leaves 3foliolate to pedately 5- to 7-foliolate, coriaceous, glabrous on both surfaces, the adaxial surface nerves quite conspicuous, the abaxial surface nerves prominent, the petioles $6.7-11.6 \mathrm{~cm}$ long; terminal leaflets $13.6-20.5 \times 4.2-9.4 \mathrm{~cm}$, lanceolate, acuminate, acute at base, obscurely dentate, the petiolules $0.6-3.3 \mathrm{~cm}$ long; lateral leaflets $5.8-13.4 \times 2.6-$ $6.7 \mathrm{~cm}$, lanceolate, rounded at base, the apex and margin as in terminal leaflets, the petiolules $0.4-2.5 \mathrm{~cm}$ long. Inflorescence a dichotomouscymes, peduncles $0.5-2.1 \mathrm{~cm}$ long. Staminate flowers ca. $2 \mathrm{~mm}$ long, ovoid. Pistillate flowers ca. $5 \mathrm{~mm}$ long, oblong, the staminode ca. $0.5 \mathrm{~mm}$, the stigma-lobe rounded, ciliolate. Berries $1.5-2.0 \mathrm{~cm}$ in diameter, globose, 1-2-seeded; seeds $1.2 \times 0.6 \mathrm{~cm}$, oblong, the testa rugulose, the endosperm $\mathrm{M}$-shaped in cross-section.

Specimens Examined. BORNEO. Sarawak. Mount Pueh, Sematan, KP4, 12 November 2014; KP15, 24 October 2015; KP16; KP17, 24 October 2015; Tapak Rafflesia Kampung Temurang (Padawan), KT2, 10 November 2015.

Distribution. India, Myanmar, Thailand, Vietnam, Sarawak, Sabah and Kalimantan.

Ecology and Habitat. It is mostly found on the margin of lowland dipterocarp forests, frequently on limestone outcrops and hill dipterocarp forests. In Sarawak, the species is recorded to inhabit on yellow sandy clay soil, near the river bank, and frequently on lowland kerangas forests. It is found in the mixed dipterocarp forests to lower montane forests. As far as it is known this is the host species for all the species of Rafflesia in Malesia except for R. keithii and R. kerrii.

Observations. It is recognised by its lanceolate, nondentate leaflets, and globose berries. In Peninsular Malaysia the 
TABLE 1: List of species names, collection numbers, collection dates, localities, and collectors of Tetrastigma species collected from four different populations.

\begin{tabular}{|c|c|c|c|c|}
\hline Species name & Collection number & Date & Locality & Collectors \\
\hline T. diepenhorstii & GG19 & 5 December 2014 & Gunung Gading NP & WN Fatiha \\
\hline T. diepenhorstii & GG23 & 31 December 2014 & Gunung Gading NP & WN Fatiha \\
\hline T. diepenhorstii & GG26 & 30 April 2015 & Gunung Gading NP & WN Fatiha \\
\hline T. diepenhorstii & GG28 & 22 June 2015 & Gunung Gading NP & WN Fatiha \\
\hline T. diepenhorstii & GG32 & 9 July 2015 & Gunung Gading NP & WN Fatiha \\
\hline T. diepenhorstii & GG34 & 1 August 2015 & Gunung Gading NP & WN Fatiha \\
\hline T. diepenhorstii & GG36 & 20 September 2015 & Gunung Gading NP & WN Fatiha \\
\hline T. diepenhorstii & GG38 & 22 October 2015 & Gunung Gading NP & WN Fatiha \& M Muklis \\
\hline T. diepenhorstii & BASP3 & 4 August 2015 & Batang Ai NP & Connie Geri \\
\hline T. diepenhorstii & KP2 & 26 May 2014 & Mt Pueh & WN Fatiha \\
\hline T. rafflesiae & KP4 & 12 November 2014 & Mt Pueh & WN Fatiha \\
\hline T. diepenhorstii & KP5 & 12 February 2014 & Mt Pueh & WN Fatiha \\
\hline T. diepenhorstii & KP10 & 24 October 2015 & Mt Pueh & WN Fatiha \& M Muklis \\
\hline T. diepenhorstii & KP11 & 24 October 2015 & Mt Pueh & WN Fatiha \& M Muklis \\
\hline T. rafflesiae & KP15 & 24 October 2015 & Mt Pueh & WN Fatiha \& M Muklis \\
\hline T. rafflesiae & KP16 & 24 October 2015 & Mt Pueh & WN Fatiha \& M Muklis \\
\hline T. rafflesiae & KP17 & 24 October 2015 & Mt Pueh & WN Fatiha \& M Muklis \\
\hline T. diepenhorstii & KT1 & 10 November 2015 & Tapak Rafflesia Kampung Temurang (Padawan) & WN Fatiha \& M Muklis \\
\hline T. rafflesiae & KT2 & 10 November 2015 & Tapak Rafflesia Kampung Temurang (Padawan) & WN Fatiha \& M Muklis \\
\hline T. rafflesiae & KT5 & 5 April 2016 & Tapak Rafflesia Kampung Temurang (Padawan) & WN Fatiha \& M Muklis \\
\hline
\end{tabular}

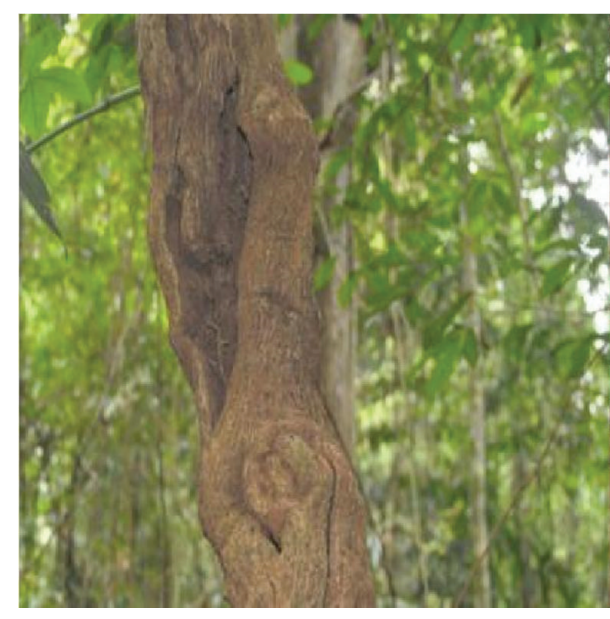

(a)

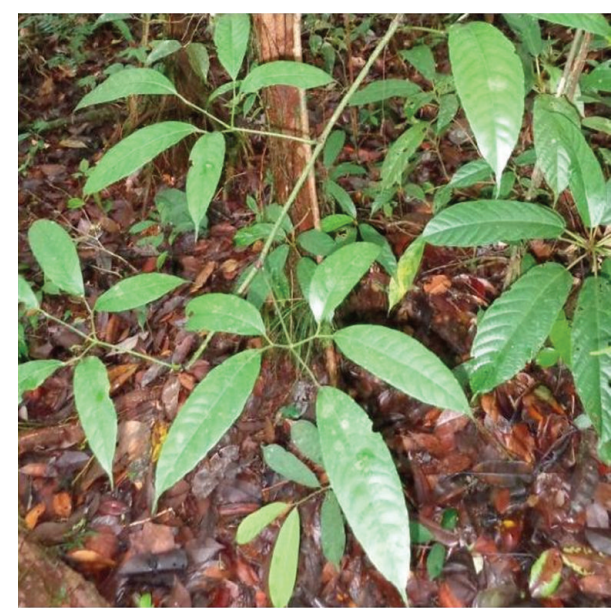

(b)

FIgURE 1: Tetrastigma rafflesiae collected from Mount Pueh, Sematan. (a) Older stem terete. (b) Pedately 5 leaflets.

species is most widely distributed, being recorded from various habitats throughout. In Sarawak, the species is mostly found at lower elevations. It is believed to be the host of the Rafflesia buds found in Ranau (Coll. number SP4308). It can climb up to the height of $7 \mathrm{~m}$. The stem is black, peduncle and pedicel are green, and fruits are light green.

Tetrastigma diepenhorstii (Miq.) Latiff (Figure 2). Tetrastigma diepenhorstii (Miq.) Latiff, Folia Malays. 2(3): 185. - Cissus diepenhorstii Miq., Fl. Ind. Bat. Supp. 1 (1860-61) 515 - Type: Indonesia, Sumatera, Priaman, Diepenhorst s.n. (Isotype L !)

Synonym. Tetrastigma trifoliolatum Merr., Philip. J. Sci. 9,4 (1914) 370 et Enum. Philip. Fl. Plt. 3 (1923) 5; Suesseng. in
Engler \& Prantl, Natur. Pflanzenfam. ed. 2, 20d (1953) 326 Type: The Philippines, Leyte, C.A. Wenzel 544.

Vernacular Name. Pupus, Pumpaos (Dusun, Sabah), Akar engkaranda, Bulunka (Iban, Sarawak).

Climbing shrubs, large, climbs up to ca. $20 \mathrm{~m}$ long. Tendrils simple, glabrous. Stems $0.5-1.5 \mathrm{~cm}$ in diameter, striate, pustulate. Tendrils simple. Leaves 3-foliolate, coriaceous, glabrous, abaxial surface chocolate-coloured, the petioles $6.5-17.2 \mathrm{~cm}$ long; terminal leaflets $10.2-20.4 \times 4.2-$ $11.3 \mathrm{~cm}$, elliptical, apex acuminate, base cuneate, margin subentire to grossly dentate, the petiolules $3-8.0 \mathrm{~cm}$ long; lateral leaflets $9-18 \times 3.5-10.5 \mathrm{~cm}$, ovate-elliptic, base obtuse, 


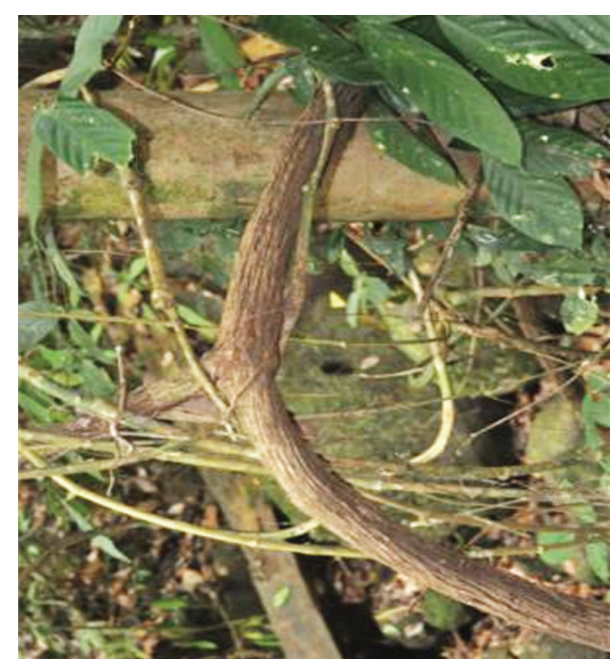

(a)

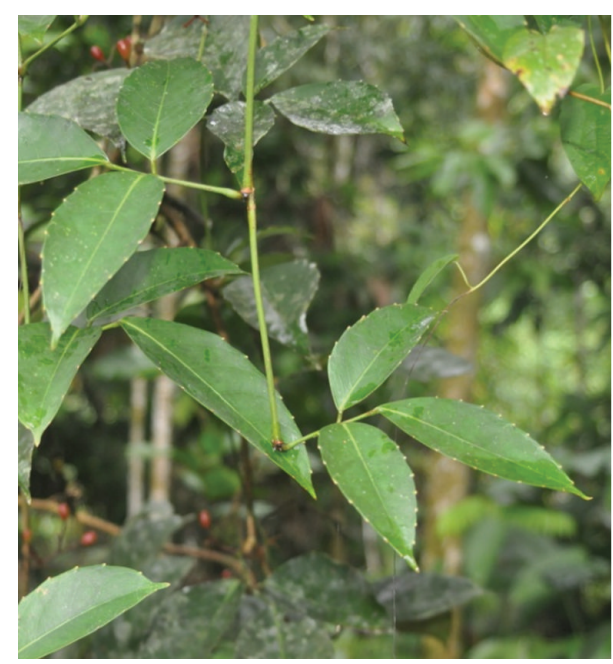

(b)

FIGURE 2: Tetrastigma diepenhorstii collected from Gunung Gading National Park, Lundu. (a) Older stem rounded. (b) Three leaflets.

apex and margin as in terminal leaflets, the petiolules $0.4-$ $2.7 \mathrm{~cm}$ long. Inflorescence a dichotomous cyme, ca. $4.5 \mathrm{~cm}$ across, ultimate axis umbelules, peduncles ca. $0.5-2 \mathrm{~cm}$ long, bracteate. Staminate flowers minutely pubescent, obovoid, ca. $2 \mathrm{~mm}$ long, pedicels ca. $1 \mathrm{~mm}$ long, calyx cupuliform, margin lobed, petals obovate, $1.8 \times 0.7 \mathrm{~mm}$, saccate, filaments ca. $0.6 \mathrm{~mm}$, anthers oblong $1.0 \times 0.8 \mathrm{~mm}$. Berries ellipsoid, $1.0 \times$ $0.7 \mathrm{~cm}$, cerebriform or smooth, 1 -seeded; Berries ellipsoid, 1.0 $\times 0.7 \mathrm{~cm}$, cerebriform or smooth, 1 -seeded; seeds $0.9 \times 0.5 \mathrm{~cm}$, broadly ellipsoid, the testa reticulate, the endosperm basically $\mathrm{M}$-shaped in cross-section but with a few lateral growths.

Specimens Examined. BORNEO. Sarawak, Gunung Gading National Park, Lundu, GG19, 5 December 2014; GG23, 31 December 2014; GG26, 30 April 2015; GG28, 22 June 2015; GG32, 9 July 2015; GG34, 1 August 2015; GG36, 20 September 2015; GG38, 22 October 2015; Batang Ai National Park, BASP3, 4 August 2015; Mount Pueh, Sematan, KP2, 26 May 2014; KP5, 12 February 2015; KP10, 24 October 2015; KP11, 24 October 2015; Tapak Rafflesia Kampung Temurang (Padawan), KT1, 10 November 2015.

Distribution. Malesia: Sumatera, Borneo and The Philippines.

Ecology and Habitat. In Sumatra it is known to occur on sandy soil of depleted open secondary forests at ca. $20 \mathrm{~m}$ elevation. But in Sabah (Borneo) it is observed to occur from mangrove forest edge to the mountain ridges as high as $1100 \mathrm{~m}$ elevation at Mt. Kinabalu. It is also the known host for Rafflesia keithii, an endemic species to Borneo Coll. number SNP4088 [1, 11]. In Sarawak (Borneo) it was reported from the mixed dipterocarp to submontane forests at altitude ranging from 110 to $1100 \mathrm{~m}$ above sea level. It has also been reported that the local fishes, such as Sema and Tengadak are attracted to the berries when they fall into the river.
Observation. It is recognised by its coriaceous leaflets, secondary reticulation very conspicuous, the terminal petiolules about five times as long as the lateral ones, peduncles are very short, bracteate and the berries are ellipsoid. It is closely similar to $T$. curtisii in terms of its conspicuous nerves between the secondary venations.

During field samplings, some of the host plants were not able to be collected together with the Rafflesia due to several limitations. First, there were no climbing lianas around or near Rafflesia tuan-mudae when collections were made. This could be due to the growth habit of lianas of which the stems are very flexible and tend to grow and climb in all directions [13]. Second, the leaves of the host plant were too high in the canopy thus we were unable to collect materials for voucher specimens. This is possibly due to the presence of tendrils that are helical in shape and tend to coil to other nearby plants allowing the lianas to climb to sufficient height to catch the sunlight $[1,14]$. Figure 3 shows the blooming flower of $R$. tuan-mudae and its host plants which were collected together.

\section{Conclusion}

This is the first detailed study reporting the host plants of $R$. tuan-mudae as both T. rafflesiae and T. diepenhorstii in Sarawak, Malaysia. This finding is therefore crucial in identifying a need to conserve both host plants of $R$. tuanmudae, in order to preserve the population of $R$. tuan-mudae.

\section{Competing Interests}

The authors declare that they have no competing interests. 


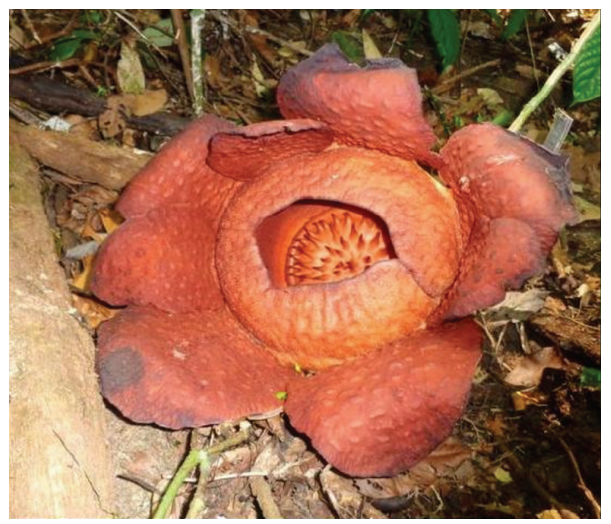

(a)

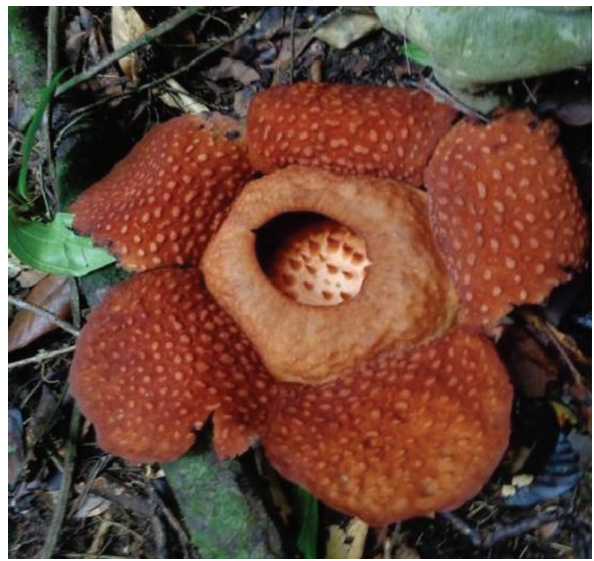

(c)

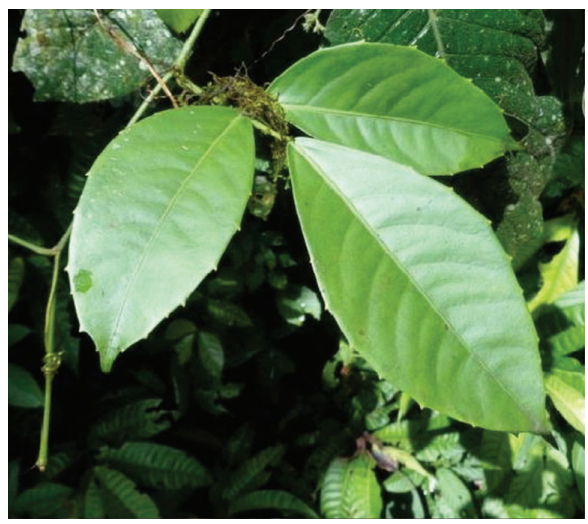

(b)

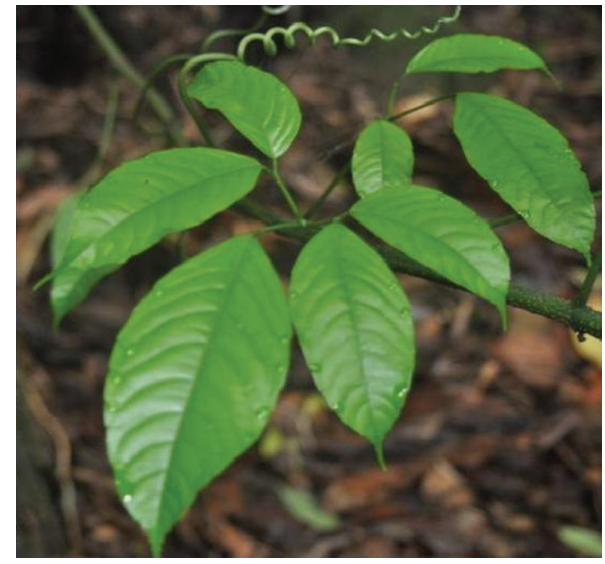

(d)

Figure 3: Rafflesia tuan-mudae and its host plant. (a) Flower of R. tuan-mudae collected at Gunung Gading National Park, Lundu. (b) Host plant, T. diepenhorstii (Coll. number GG34). (c) Flower of R. tuan-mudae collected at Mount Pueh, Sematan. (d) Host plant, T. rafflesiae (Coll. number KP4).

\section{Acknowledgments}

This study was supported by the NRGS 1087/2013(01) grant of the Ministry of Education, Malaysia, and Universiti Malaysia Sarawak.

\section{References}

[1] J. Nais, Rafflesia of the World, Natural History Publications, Sabah, Malaysia, 2001.

[2] D. S. Balete, P. B. Pelser, D. L. Nickrent, and J. F. Barcelona, “Rafflesia verrucosa (Rafflesiaceae), a new species of small-flowered Rafflesia from eastern Mindanao, Philippines," Phytotaxa, vol. 10, pp. 49-57, 2010.

[3] J. F. Barcelona, E. S. Fernando, D. L. Nickrent, D. S. Balete, and P. B. Pelser, "An amended description of Rafflesia leonardi and a revised key to Philippine Rafflesia (Rafflesiaceae)," Phytotaxa, vol. 24, no. 1, pp. 11-18, 2011.

[4] N. Sofiyanti, K. Mat-salleh, K. Mahmud, N. Z. Mazlan, M. R. Hasein, and D. F. Burslem, "Rafflesia parvimaculata (Rafflesiaceae), a new species of Rafflesia from Peninsular Malaysia," Phytotaxa, vol. 253, no. 3, pp. 207-213, 2016.

[5] A. Susatya, W. Arianto, and K. Mat-Salleh, "Rafflesia bengkuluensis (Rafflesiaceae), a new species from South Sumatra, Indonesia," Folia Malaysiana, vol. 6, pp. 139-152, 2006.
[6] H. Wiriadinata and R. Sari, "A new species of Rafflesia (Rafflesiaceae) from North Sumatra," Reinwardtia, vol. 13, pp. 95-100, 2010.

[7] P. Chen, L. Chen, and J. Wen, "The first phylogenetic analysis of Tetrastigma (Miq.) Planch., the host of Rafflesiaceae," Taxon, vol. 60, no. 2, pp. 499-512, 2011.

[8] A. Latiff, "Studies in Malesian Vitaceae, VII. The genus Tetrastigma in the Malay Peninsula," Garden's Bulletin, vol. 36, part 2, pp. 213-228, 1983.

[9] W. Meijer, "Rafflesiaceae," Flora Malesiana Series 1, no. 13, pp. $1-42,1997$.

[10] C. Niyomdham and R. Kubat, "Balanophoraceae and rafflesiaceae in Thailand," in Proceedings of the 4th ISPFP Parasitic Flowering Plants, H. Weber and W. Forsteuter, Eds., Marburg, Germany, August 1987.

[11] A. Latiff, "Studies in Malesian Vitaceae XII: taxonomic notes on Cissus, Ampelocissus, Nothocissus, Tetrastigma and other genera," Folia Malaysiana, vol. 2, no. 3, pp. 179-189, 2001.

[12] E. A. M. Zuhud, A. Hikmat, and N. Jamili, Rafflesia Indonesia, keanekaragaman, Ekologi dan Pelestariannya, Institut Pertanian Bogor, Indonesia: Yayasan Pembinaan Suaka Alam dan Suaka Margasatwa Indonesia (The Indonesian Wildlife Fund) dan Laboratorium Konservasi Tumbuhan, 1998. 
[13] S. A. Schnitzer and F. Bongers, "The ecology of lianas and their role in forests," Trends in Ecology and Evolution, vol. 17, no. 5, pp. 223-230, 2002.

[14] J.-S. Wang, G. Wang, X.-Q. Feng et al., "Hierarchical chirality transfer in the growth of towel gourd tendrils," Scientific Reports, vol. 3, article 3102, 2013. 

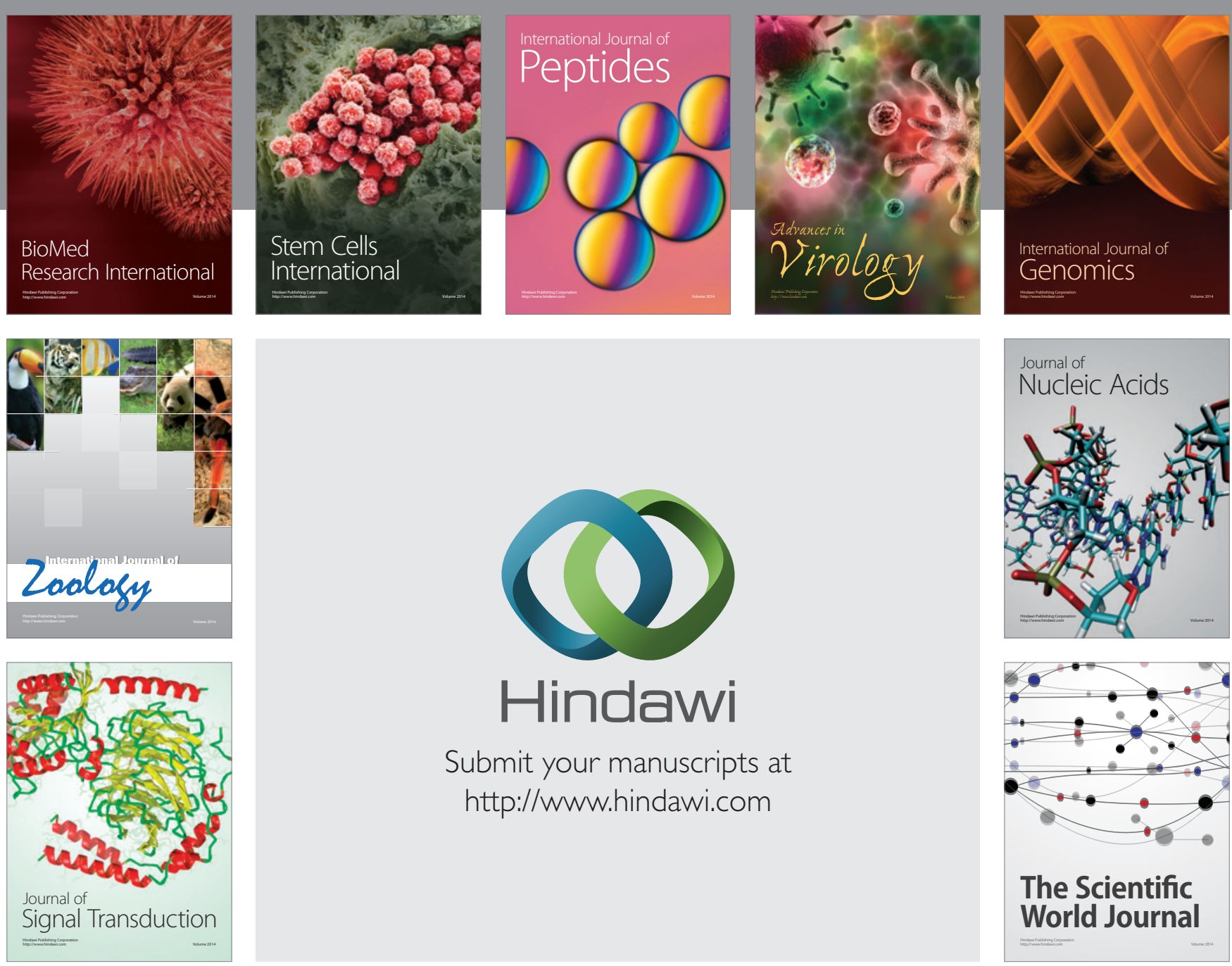

Submit your manuscripts at

http://www.hindawi.com
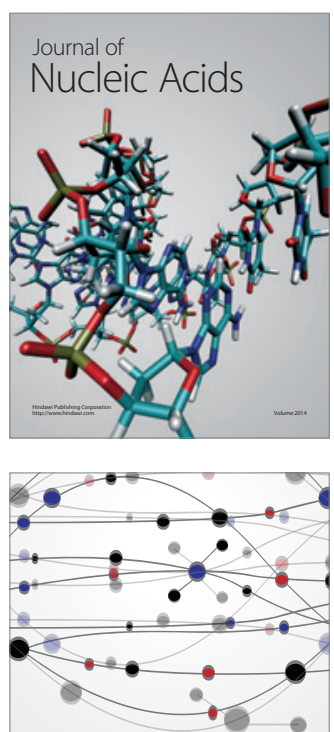

The Scientific World Journal
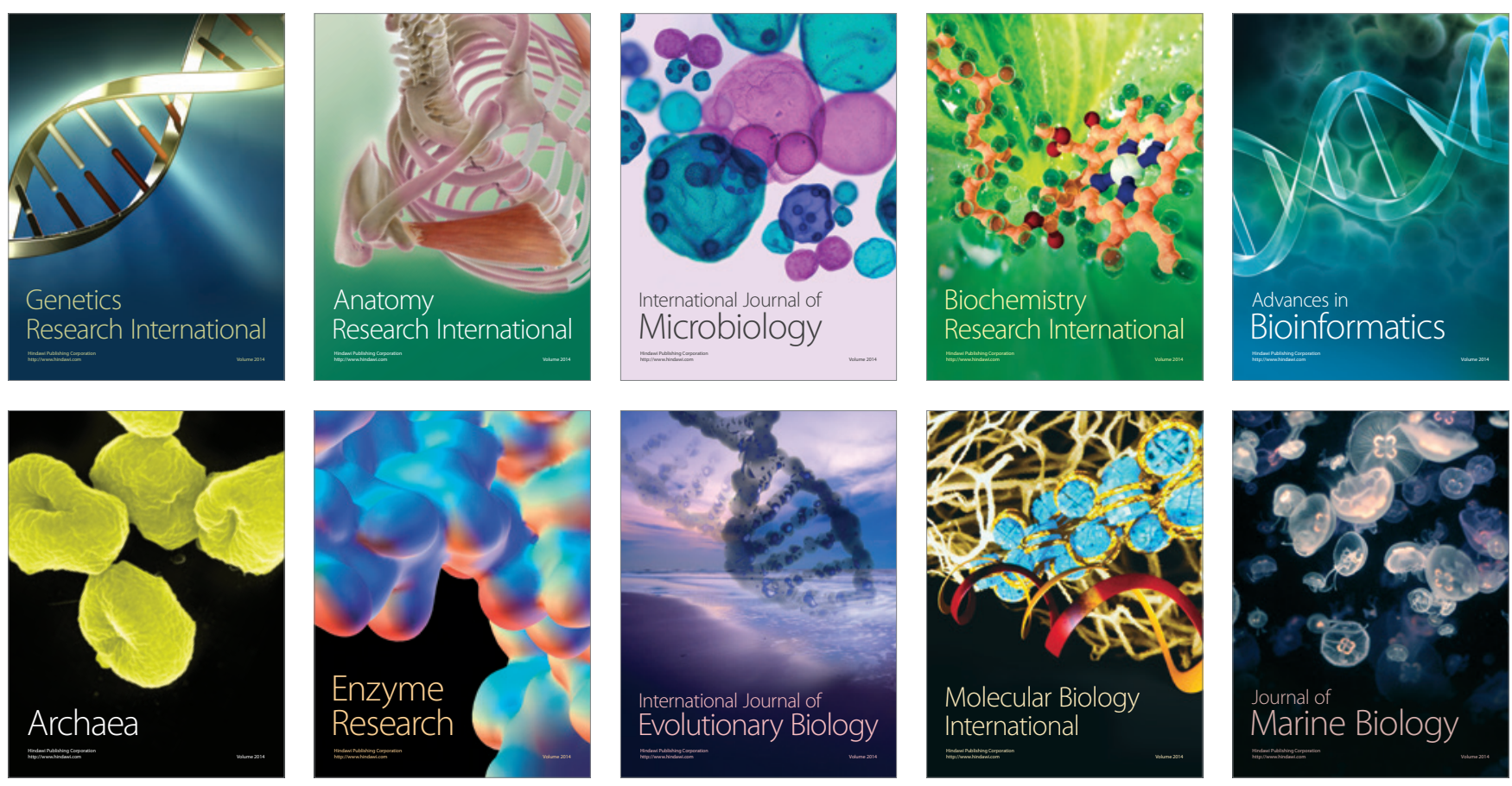